\title{
The predictive state: Science, territory and the future of the Indian climate
}

\section{Martin Mahony}

Science, Society and Sustainability (3S) Research Group, School of Environmental Sciences, University of East Anglia

\section{Abstract}

Acts of scientific calculation have long been considered central to the formation of the modern nation-state, yet the transnational spaces of knowledge generation and political action associated with climate change seem to challenge territorial modes of political order. This paper explores the changing geographies of climate prediction through a study of the ways in which climate change is rendered knowable at the national scale in India. The recent controversy surrounding an erroneous prediction of melting Himalayan glaciers by the Intergovernmental Panel on Climate Change (IPCC) provides a window onto the complex and at times antagonistic relationship between the Panel and Indian political and scientific communities. The Indian reaction to the error, made public in 2009, drew upon a national history of contestation around climate change science, and corresponded with the establishment of a scientific assessment network (INCCA) which has given the state a new platform on which to bring together knowledge about the future climate. I argue that INCCA is indicative of the growing use of regional climate models within longer traditions of national territorial knowledge-making, allowing a re-scaling of climate change according to local norms and practices of linking scientific knowledge to political action. I illustrate the complex co-production of the epistemic and the normative in climate politics, but also seek to show how co-productionist understandings of science and politics can function as strategic resources in the ongoing negotiation of social order. In this case, scientific rationalities and modes of environmental governance contribute to the contested epistemic construction of territory and the evolving spatiality of the modern nation-state under a changing climate.

Keywords: climate change; co-production; territory; IPCC; India; controversy

\section{Corresponding author:}

Martin Mahony, School of Environmental Sciences, University of East Anglia, Norwich Research Park, Norwich NR4 7TJ, United Kingdom.

Email:m.mahony@uea.ac.uk

\section{Introduction}


In late 2009, it emerged that a statement that had been made in the Working Group II report of the Intergovernmental Panel on Climate Change (IPCC) 4th Assessment Report was incorrect. The report stated that 'glaciers in the Himalayas are receding faster than in any other part of the world and, if the present rate continues, the likelihood of them disappearing by the year 2035 and perhaps sooner is very high' (IPCC, 2007: 493). This (probabilistically hedged) prediction was found to have been made on unreasonable grounds. Indeed, it emerged that the year 2035 had originated in a glaciologist's statement in a magazine interview in the late 1990s, and had found its way into the IPCC report via a number of non-peer reviewed publications (or 'grey literature'; for a detailed account see Banerjee and Collins, 2010).

While the 2035 claim had not been headline news on the publication of AR4, perhaps because it was not included in Working Group II's Summary for Policymakers nor in the synthesis summary, the figure caused some unease in both political and glaciological communities in India and elsewhere. The importance of glacial meltwaters for agriculture, industry and human livelihoods across northern India positions the Himalayan region as a key site of scientific and political concern (e.g. Moors et al., 2011). The journalist involved with breaking the IPCC story in the news section of Science was born on the banks of the Ganges, perhaps India's most famous glacier-fed river. ${ }^{1}$ He stated in an interview with me that:

there is a deep connection in my personal life for the Ganges and for Gangotri glacier. And when this [IPCC] report came out I was aghast. I was taken aback, thinking 'how can this happen?' And then I started hearing murmurs from Indian glaciologists saying 'the IPCC has got it wrong'. But remember, IPCC is 2,500 of the top-notch scientists so they are looked upon as a very august body. So nobody was going to come on record. Glaciologists... they work very slowly. Glaciers move slowly, glaciologists also move slowly. It took them time before that murmur became a little louder. And then we started looking at it carefully. In 2009 I started looking at it very vigorously. Then the murmur became a little louder. (interview, 6 March 2012, New Delhi) 
The 'murmurs' were also picked up by Jairam Ramesh, then Minister of Environment and Forests. Apparently sensing not only some perplexity about the 2035 claim, but also a measure of disagreement within the glaciological community about the true status and prospects of the Himalayan glaciers, Ramesh commissioned a review of existing knowledge produced by Indian scientists. A prominent glaciologist was persuaded out of retirement to conduct the review, which concluded that there is a mixed picture of receding and advancing glaciers in the Himalayan range, and that no trend can be attributed to anthropogenic climate change (Raina, 2009). This conclusion was reported in Science in the context of refuting the IPCC claim about Himalayan glaciers melting by 2035 (Bagla, 2009).

The same journalist who narrated the story of these counterposed scientific assessments in Science also filed a report for New Delhi Television, a major English-language television channel in India. In response to the news segment, the chair of the IPCC, Indian scientist Rajendra Pachauri, famously dismissed the Indian government report as 'voodoo science', questioning the evidential basis and scientific rigour of the report. ${ }^{2}$ The term 'voodoo science' functioned as an instance of boundary work, an effort to delineate what is to count as legitimate scientific knowledge, and what is to count as mere belief, superstition, or ideology (Gieryn, 1983). ${ }^{3}$ This controversy sparked important reframings of the relationships between the IPCC, the Indian government, and national and international modes of political knowledge-making and action. The so-called Himalayagate or Glaciergate incident ${ }^{4}$ reanimated a history of scientific and political contestation that has shaped the relationship between climate politics and national space in India. This relationship informed the emergence of a new national assessment body, the Indian Network for Climate Change Assessment (INCCA), under the direction of Jairam Ramesh. As scholars of science and technologies studies (STS) have shown, moments of controversy can bring the contested practices, norms and politics of knowledge-making into the open, as various actors seek to translate emergence and flux into stability and order (e.g. Jasanoff, 2004a; Whatmore, 2009). Himalayagate and INCCA thus offer an opportunity to study the relations between international and national modes of knowledge production, and the potential of international science, such as that represented and mobilised by the IPCC, to travel and be translated into diverse national contexts and political cultures (Hulme, 2010a; Jasanoff, 2010; Lahsen, 2007; Livingstone, 2003). These political cultures bear upon the evolution of 
the forms of knowledge from which national governments draw certain understandings of and commitments to the climate change issue. In India, INCCA is a site at which scientific prediction and the governance of a national space have been brought into conversation with each other. I analyse this development in relation to a broader history of national environmental knowledge-making that points towards a distinctive 'civic epistemology' (Jasanoff, 2005a). I suggest that regional climate prediction constitutes a new form governmental gaze, with both its own effects and its own potential blind-spots. Therefore, this predictive knowledge arguably represents an important juncture in the history and use of the notion of 'territory'.

\section{Knowing and producing territory}

Climate change, understood as an epistemic and political object defined by globality and the pursuit of a transnationally enlightened polity (Jasanoff, 2010; Hulme, 2010b), generates frictions with conventional modes of ordering the relationship between science and politics in the system of territorially-bounded nation-states. In the history of the modern nationstate, territory has been both a central object and means of governing. In conventional discourses of international relations, both academic and public, territory is often conceived as the bounded space over which nation-states exercise a unique sovereignty (e.g. Weber, 1946). However, a strand of work in political geography and related disciplines has sought to dig deeper into this notion of territory. The effort here is to not take national territories for granted as spatial units (a move characterized by John Agnew (1994) as the 'territorial trap'), but rather to problematize and historicize territory as both political object and political technology. That is, 'territory' is understood to refer to both a thing to be known and controlled, and to a means of achieving certain goals which precede territory-as-object (Braun, 2000; Elden, 2007; 2010). Territory can therefore be seen as being constructed, perhaps most visibly through calculative and representational techniques such as cartography (Crampton 2010; Edney, 1997; Winichakul, 1994;). The well-worn adage of the critical cartographer - 'the map precedes the territory' (Baudrillard, 1983: 2) - captures the notion that the will to map space, often with the aim of, for example, better organizing the network of property rights, is central to the emergence of the territorially bounded nationstate (Elden, 2010; Pickles, 2004; Wood, 1992). In this paper, I seek to explore the coevolution of practices of territorial calculation with the shifting norms and discourses of 
Indian climate politics. Thinking territory and politics together in this way may be aided by turning to the notion of co-production.

The notion of co-production, broadly defined, holds that 'the ways in which we seek to know and represent the world ... are inseparable from the ways in which we choose to live in it' (Jasanoff, 2004b: 2; see also Ezrahi, 1990; Jasanoff, 2011; Shapin and Schaffer, 1985). In this understanding, knowledge and forms of political order mutually construct one another. Epistemic commitments to what 'is' are inseparable from normative commitments to what 'ought to be' (e.g. Hulme, 2009). The co-productionist approach can help make sense of how the cognitive, institutional, material and normative elements of a society are interlinked (Jasanoff, 2004a), thus offering explanatory resources for observable changes in the configurations of science and politics (cf. Lövbrand, 2011; Miller, 2004). As I demonstrate below, an understanding of science and politics as being tightly coupled has had particular traction in recent Indian environmental politics. The events I describe highlight how the boundaries can become blurred between co-production as an analytic lens and as a strategic instrument wielded by powerful and knowledgeable actors (Jasanoff, 2004c: 281).

The state is a key site of co-productionist inquiry, and such an approach offers a number of synergies with theories which emphasise the roles of representation and spatial standardization in the development and functioning of the state (Anderson, 1983; Goswami, 2004; Mitchell, 2002; Scott, 1998). In such terms, the nation-state can be conceived as 'a network that is partly held together by circulating technologies of representation and communication' (Jasanoff, 2004a: 26; Sharma and Gupta, 2006). For example, in his history of forestry in colonial eastern India, Sivaramakrishnan (1999) argues that the project of state-making was intimately bound with the politics of knowledge and expertise. Although the history of colonial forestry can be read as the straightforward imposition of a 'Western' science on the complex social ecologies of Indian woodlands, Sivaramakrishnan argues that the spatial rationalities of scientific forestry were, in fact, confounded both by local ecological realities and by political resistances to the colonial state (see also Gadgil and Guha, 1993). The idiom of co-production, when brought to bear on Sivaramakrishnan's analysis, highlights the emergent quality of political rule. Colonial power is not simply applied unilaterally, but rather made to conform to the local particularities with which it is confronted. Turning from the national to the international, contemporary climate change 
offers new cosmopolitan networks of knowledge production in the form of transnational spaces like the IPCC (Beck et al., 2013; Hulme, 2010a) and globally circulating tools of climate prediction (Mahony and Hulme, 2012). Seen from a certain normative standpoint, the international coordination of climate science-for-policy can be interpreted as a 'cosmopolitan moment' (Beck, 2009: 47) that challenges national forms of epistemic and political sovereignty by presenting global risks, knowledges and political power (Beck, 2009; Whitehead, Jones and Jones 2007). However, it would be wrong to suggest that global climate science and politics erase local specificities. Indeed, work in STS has highlighted the translation or localization of knowledges that claim universal reach (e.g. Jasanoff, 2005a; Jasanoff and Martello, 2004; Wilson Rowe, 2012).

Evident in the above is that political orders are never entirely stable, nor are they ever simply 'given'. Rather, they emerge out of the interplay between material and discursive resources in ways that are not necessarily predictable but are nonetheless amenable to empirical analysis. In what follows I aim to make such an empirical exploration of the tensions between transnational networks of knowledge production, the localization of global climate science, and the ongoing co-production of territory and climate politics.

Despite clear synergies, co-productionist accounts of social ordering have not yet been brought into conversation with emerging geographical understandings of the nature and enduring political import of territory. Indeed, with a few exceptions (e.g. Miller, 2004; Jasanoff 2004d), the co-productionist strand of STS has yet to fully embrace questions of space and spatial organisation. In taking a symmetrical approach to the evolution of epistemic and political forms, the lens of co-production offers a powerful way of comprehending territory not as a historical a priori, but as a contingent product of particular forms of cognitive and normative development, a compound of economic, legal, strategic and technical forces whose changing interrelations lend territory its historic and cultural specificities (Elden, 2010). By studying a moment of both controversy and emergence at the science-policy interface in India, I aim to illustrate the local co-production of climate science and politics and to unpack the continuing significance of national territory in the face of cosmopolitan challenges to the territorial logics of the modern nation-state.

\section{Sources and methodology}


This article is based predominantly on fieldwork conducted in New Delhi in February and March of 2012. I carried out 27 interviews with scientists participating in both IPCC and INCCA, and with journalists, politicians and non-governmental organisation (NGO) actors. Previous characterisations of Indian environmental politics describe a space of multiple voices and competing epistemic and normative commitments (e.g. Dubash, 2011; Jasanoff, 2007). As illustrated below, the evolution of the Indian government's position on climate change has not occurred in an institutional vacuum (see also Atteridge et al., 2012). Rather, a diverse array of actors has participated in the process of defining and deliberating the knowledge to which governmental actors have deferred in climate change debates. Responding to this diversity through a sampling strategy which traversed networks of scientific, political, NGO and media actors was therefore a response to the particular characteristics of Indian environmental knowledge-making, but also an attempt to operationalize the co-productionist stance on the relation between the epistemic and the normative. If scientific and political concerns cannot be neatly distinguished from one another, it follows that the scientific and political work of responding to climate change happens in a number of different settings. By identifying prominent actors through documentary analysis, lists of IPCC participants and notes on recent national climate change conferences, for example, I gained a measure of heterogeneity within my field of analytic vision.

Documents were collected through Internet searches and from the library of the New Delhibased environmental NGO the Centre for Science and Environment (CSE). A survey of the major English-language daily newspapers was also conducted through the LexisNexis online database of news reports. The search terms 'climate', 'global warming', 'IPCC', 'Himalaya', 'glaciers' and 'INCCA' were used to identify relevant news articles. Along with the other documents and interview transcripts, these were subject to interpretive content analysis which drew on the tools of grounded theory (Charmaz, 2006). This involved close thematic coding of the texts and the building-up of conceptual categories (such as 'credibility') through iteration between the data and the conceptual interests introduced above.

In the next section I situate the IPCC glacier controversy within a longer history of national environmental politics and epistemic contestation. I then explore how this incident and this 
history informed the emergence of INCCA, before offering conclusions about the coproduction of new territorial knowledges and new forms of climate politics.

\section{A lineage of contestation}

The controversy over melting Himalayan glaciers points towards a longer history of occasional antagonism between epistemic claims made in the global North and claims made in India. In what may have been the first popular presentation in India of the climate change issue, a contestation over the science and its implications took centre-stage. In 1982 the Centre for Science and Environment (CSE) produced its first 'Citizens' Report' on the 'State of India's Environment', the first of a series of reports that sought to present the Indian environment as a national object through the lens of political economy and an overriding concern for environmental and social justice. In introducing the topic of climate change, the report took issue with a statement by British scientist John Gribben in New Scientist magazine that:

although the third world countries will produce the greenhouse problem by the early 21st century... they will suffer little adverse consequences themselves, and may even benefit as a result. Meanwhile, their traditional enemies in the rich North will suffer the worst consequences of the developing world's carbon pollution. (quoted in Agarwal, Sharma and Chopra, 1982: 87)

This position was challenged by the marshalling of a range of evidence, including emerging modelling studies which suggested that the tropics and sub-tropics would see perturbed rainfall patterns that would put the region's agriculture at risk. The CSE authors also took issue with Gribben's characterisation of the shifting responsibility for climate change. The authors foregrounded arguments about the historic responsibility of the North and the need to allow developing countries to continue on the path of industrialization:

Rich countries should not be allowed to argue in the future that the fuel consumption of developing countries ought to be kept in check to control the increase in carbon dioxide, regardless of their own contribution in the past. (Agarwal, Sharma and Chopra, 1982: 90) 
This was the first manifestation of an argument that would come to define not just CSE's position on climate change, but also the Indian government's. In a highly influential volume in 1991, CSE directors Anil Agarwal and Sunita Narain famously argued against a World Resources Institute (WRI) report by stating that emissions should be counted on a per capita basis in order to work the differential historic responsibility for climate change into global calculations of how the mitigation burden should be shared (Agarwal and Narain, 1991). They also argued for a distinction to be made between 'luxury' and 'survival' emissions, suggesting that a molecule of carbon dioxide in the atmosphere does not have a universal status. That is, carbon dioxide produced in a wood-burning stove in rural India has a profoundly different ethical (and therefore, the authors suggest, legal) status from that expelled from the tailpipe of an oversized vehicle in the United States.

This notion of common but differentiated responsibility based on per capita emissions became a cornerstone of India's negotiating position in the UN Framework Convention on Climate Change (UNFCCC) and the rationale behind the refusal to accept binding emissions cuts (Atteridge et al., 2012; Stevenson 2011). However, I want to draw attention to the episode's entangling of the epistemic and the normative, the intimate relation between assertions of what is and conceptions of what ought to be. This is a widely-reported characteristic of much environmental knowledge making in India (e.g. Jasanoff, 2004d, 2005b, 2007; Lele, 2011), with bodies like CSE foregrounding their arguments for social and environmental justice in any analytic descriptions of the state of the environment.

Contestations such as these continued, for example in the deeply normative struggle over the economic valuation of an individual human life in the IPCC's Second Assessment Report (Masood, 1995), and in the contestation between US and Indian scientists over how much methane was estimated to be emitted from India's rice fields (Parashar et al., 1996).

The Indian government and the IPCC

Incidents such as the aforementioned moments of contestation have led some observers to claim that the attention of the relevant arms of the Indian government has been focused on the UNFCCC negotiations and the preservation of the norm of differentiated responsibility, rather than on the process of producing IPCC assessments. For example, in 2001 Frank Biermann reported a lack of government interest in fostering greater participation of Indian 
experts in the IPCC process, both in terms of helping scientists to take part as authors (e.g. by publicising the recruitment process or offering financial support for travel to international meetings ${ }^{5}$ ), and in terms of ensuring wide participation of Indian experts in the review process (Biermann, 2001; see also Kandlikar and Sagar, 1999).

A persistent sense of the government's relative lack of concern for the IPCC process was also offered by my interview respondents. In relation to the Indian government's modest effort at garnering review comments and public scrutiny of IPCC documents, an Indian environmental economist working on the current IPCC report surmised:

The fact that not much of this is done to me reveals that probably the government doesn't feel that there's much point in doing it, you see? I mean it could be lack of capacity but it could simply be a lack of interest or, as they say, you put your money where your mouth is. So this is [revealing a] preference. (interview, 17 February 2012, New Delhi)

An ocean modeller I interviewed at one of New Delhi's elite universities revealed a similar perception based on his experiences of trying to foster national-level activities to support Indian input into IPCC. He said that in response to a research proposal he submitted to an Indian science funding body, a reviewer wrote,

'So what if your science project, you want it to feed into the IPCC process, nobody reads the IPCC reports'. It was an Indian reviewer... my suspicion is fairly senior. For you to hear that, it sort of confounded a lot of things... I mean sure enough it's too thick for any one person to sit and read it all. But to say what they said indicates that it's not taken like it's important for this country. And you know, all of us had our suspicions on foreign... [laughs] and thanks to you guys [referring to my British nationality and the legacy of British colonialism in India] well, ... be that as it may, it may or may not be real but at least it plays well. (interview, March 6 2012, New Delhi)

This account begs comparison with Mikaela Sundberg's (2006) analysis of climate science research proposals in Sweden, where she found that linking proposed research to the assessment practices of the IPCC, however tangential the link might be, was seen as an essential strategy for attracting government attention and hence funding. It is apparent that 
this strategy is not as effective in India. Indeed, there is reason to think that linking work to particular national concerns such as the monsoon might be a more effective strategy for attracting funding.

My interview subjects indicated that many Indian actors regard the IPCC as being of little relevance to Indian concerns. Indeed, in more broad terms, the IPCC tended to perceived as a Western institution that challenges the epistemic sovereignty of countries like India that take a distinctive normative stance on climate change (cf. Lahsen, 2007). This framing is evident in the mainstream English-language media's coverage of the Himalayan glacier controversy in India, in statements such as:

'For the first time, the Indian government has challenged western research that says global warming has hastened the melting of Himalayan glaciers' (Hindustan Times, November 10 2009)

and:

'The western countries, [Environmental Minister Jairam Ramesh] felt, used the IPCC report to pressurise India to come on board to accept mitigation targets, which was successfully rejected' (Hindustan Times, March 16 2010)

The language of challenging and rejecting scientific claims emanating from outside India situates this particular moment of controversy in the longer lineage of epistemic contestation discussed above. The sense that the IPCC and climate science as a whole is a space where the epistemic and the normative are deeply intertwined - with the IPCC for example acting as a didactic tool to put pressure on the Indian government - is a theme voiced by a variety of different actors.

Defining the space of science and politics

For over a decade, calls have come from various NGOs in India for the government to pay greater attention to the IPCC process. Such arguments have been advanced by CSE and parts of the People's Science Movement such as the Delhi Science Forum (DSF). The People's Science Movement is a collective term for a number of civil society organizations 
that emerged after India's independence, with aims ranging from the popularization to the democratization of science and related policymaking (Varma, 2001; Visvanathan, 2005).

The DSF largely resides in this latter category. For its founder, writing in 2011, the Indian government's lack of engagement with the science of climate change has hindered its ability to gain geopolitical advantage and assert its own sovereignty in international climate debates.

Certainly as far as India goes, poor understanding of the science combined with poor geopolitical understanding and tactics, has meant ceding the upper hand to the USA and its allies to the detriment of global climate control. (Raghunandan, 2011: 170)

This argument echoes one put forward by CSE in 1999. Writing in a volume on 'Green Politics', the Centre's directors argued that:

Developing countries will continue to allow industrialized countries to lead them astray unless they learn the importance of science in global climate negotiations... Western scientific institutions have a monopoly over climate science, a fact that has often worked against developing countries in climate negotiations. (Agarwal, Narain and Sharma, 1999: 31)

While both the DSF and the CSE have been critical of Western scientific framings of climate change, that hasn't prevented them from presenting science in general as a potent analytic tool in developing climate policy. Both organizations draw on the perception that the science and politics of climate change are deeply intertwined, and that to succeed in the politics, one must be proficient in the science.

\section{The emergence of INCCA}

The responses to the IPCC glacier error drew upon a history of contested knowledge claims and of articulations of epistemic and political sovereignty. These themes also animated an institutional innovation regarded by some as the emergence of an 'Indian IPCC' (see below) which could offer independence from the under-fire science of the international body. On October 14, 2009 a national workshop was hosted by the Ministry of Environment and Forests (MoEF) to lay out plans for a comprehensive programme of climate change 
assessment. This led to the constitution of the Indian Network for Climate Change Assessment (INCCA), a nationwide network of scientists and institutions engaged with climate change research. Most of the scientists who have thus far contributed to reports are linked with government research institutions, while those residing in the more autonomous university sector have had less involvement. This is important to note, because government scientists are more disposed to participating in scientific projects that reflect and respond to national interests than university scientists, who are more likely to engage in international collaborative projects which transcend national borders. .

In May 2010, an INCCA-branded greenhouse gas emissions inventory was published (INCCA, 2010a). This was followed in November of the same year by what was known as the ' $4 x 4$ Assessment' (INCCA, 2010b), a study of the impacts of projected climate changes on four sectors (water resources, agriculture, forests and human health) in four regions of India (the Himalayan region, the North-East, the Western Ghats and the coastal region). Impacts were assessed based on national climate projections produced for the 2030s by a regional climate model run at the Indian Institute of Tropical Meteorology in Pune.

The IPCC glacier incident happened between the official establishment of INCCA and the start of the work for the $4 \times 4$ assessment. It is therefore important to consider the impact that these events had on the framing and indeed the rationale for this assessment. A 2009 Ministry of Environment and Forests document outlines the steps being taken to conduct national climate change assessments. It states:

The [IPCC] AR4 projects wide ranging implications and adverse impacts on developing countries for reasons of their lack of capacity to respond to rapid change. Alarmed by the findings, the government[s] of the countries across the world are engaged in working out the impacts and associated vulnerabilities of their economies to impending projected climate change. (MoEF, 2009: 7)

In the foreword to the $4 \times 4$ assessment by Ramesh, released around one year after the 'Himalayagate' affair, a subtle shift in discourse is evident:

we need to make the ' $3 \mathrm{M}^{\prime} \mathrm{s}^{\prime}$ - Measure, Model and Monitor - the foundation of our decision-making and we need to build indigenous capacity for this. We should not be 
dependent on external studies to tell us for example about the impact of climate change on our glaciers, on our monsoons, and indeed even on sea level rise. Indeed, recent evidence suggests the 'scientific consensus' on many of these is debatable. (INCCA, 2010b: 9)

The shift is from a picture of developing countries responding uniformly to the threatened impacts by bringing together knowledge about national vulnerabilities, to a language of autonomy and of the need to be in some sense self-sufficient when it comes to evaluating the available evidence on climate change impacts.

The language of 'our glaciers' and 'our monsoons' is significant in that here is a minister of state using terms of collective national experience and territoriality to describe masses of frozen water and features of atmospheric circulation (cf. O'Reilly 2011). Rhetorical constructions of the national are of course common to any political project (Anderson, 1983), and the wider cultural, political and environmental significance of these particular objects within (and beyond) India cannot be overstated. This mingling of the national and the nonhuman thus serves to introduce borders and territory into the supposedly borderless worlds both of science in general (Shapin, 1998) and more particularly of the study of an object constructed as quintessentially global, the climate (Miller, 2004; Hulme, 2010a).

Jairam Ramesh has offered such sentiments on numerous occasions, and often echoes the arguments put forward by the NGOs outlined above, that the science and politics of climate change are inextricably interwoven, and that to cede scientific sovereignty is to cede political sovereignty. For example, a report in an Indian daily newspaper cites the Minister as saying:

Declaring that 'science is politics in climate change; climate science is politics', Union Environment Minister Jairam Ramesh has urged Indian scientists to undertake more and more studies and publish them vigorously to prevent India and other developing countries from being 'led by our noses by Western (climate) scientists who have less of a scientific agenda and more of a political agenda. (Indian Express, June 9, 2011) 
Particularly striking here are the echoes of CSE's description of developing countries being 'led astray' by the science-laden developed countries. This open mixing of the scientific and the political, or the epistemic and the normative, is something that Sheila Jasanoff (2005b) has noted as being a characteristic of dominant modes of public knowledge making in India, or what she calls civic epistemology:. political and cultural norms by which knowledge claims within a particular political context come to be counted as authoritative and reliable bases for collective action.

This empirically-observed coupling of the epistemic and the normative parallels the STS and social constructivist insistence on the interdependence of 'fact' and 'value'. While STS scholars have suggested that the concealment of such entangling is characteristic of many Western political cultures or civic epistemologies (e.g. Ezrahi, 1990; Jasanoff, 2005a; Porter, 1995), the recent history of environmental politics in India may offer illustration of the bridging of 'the gap between co-production as an analytic approach and co-production as a strategic instrument in the hands of knowledgeable social actors' (Jasanoff, 2004c: 281). For example, Jasanoff has observed a tight coupling of the epistemic and the normative in the aftermath of the Bhopal tragedy, where an industrial gas leak in 1984 caused the deaths of an estimated 16,000 people. In this case, epistemic closure about the causes and consequences of the disaster could not be attained prior to normative closure about the patterns of responsibility and blame, and science was just one voice among many in the process of achieving closure (Jasanoff, 1988, 2007). A similar patterning of the epistemic and the normative is evident in the approach of bodies like CSE to environmental knowledgemaking, particularly in the emphasis on responsibility in climate change debates, and also in Ramesh's response both to the IPCC glacier incident and to what he saw as being shortfalls in the Indian government's ability to both know and manage climate change. In what follows, I will give further illustration of how co-productionist understandings of order and change can function as strategic resources within the co-production of knowledge and social order.

Jairam Ramesh and the re-ordering of climate science and politics

Although a number of NGO actors have been sceptical about Ramesh's approach to the international climate negotiations, the majority of my respondents viewed Ramesh quite 
favourably, particularly his grasp of scientific issues. He was widely perceived as being competent in dealing with conflicting scientific opinions on matters such as the state of the Himalayan glaciers, and an individual who worked closely with MoEF for a decade described him as having 'the mind of a scientist' (telephone interview, May 17 2012). In a similar vein, a prominent NGO actor stated in an interview that he felt that whereas scientists or other specialists may be consulted on policy issues, 'ultimately it is a clutch of politicians and bureaucrats who take policy decisions according to their own preferences and compulsions, particularly since they themselves do not have a sound understanding of the subject or where the specialists are coming from' (personal communication, January 2013). In contrast he characterised Ramesh as 'a highly educated engineer and management science guy, so he was confident in dealing with the scientific community' (interview, March 14 2012, New Delhi; see also Agarwal, 2001).

Ramesh's reputation for changing the epistemic foundations of climate governance in India has in part been enhanced by INCCA, which was largely his own innovation. However, much of the network of scientists and data that constituted INCCA was in existence prior to 2009, in the form of the network that put together India's first national communication document under the UNFCCC; this document included climate projections and some impact analysis for the last few decades of the 21st century. Although INCCA was to some degree a repackaging of already existing knowledge and capacity, for another NGO representative it represented a 'substantive and productive effort' to draw attention to the climate issue. In this sense INCCA in part reflected other examples of Jairam Ramesh instigating political initiatives on particular issues which did not necessarily 'represent a deliberate departure from past policy positions', but which 'drew attention to issues through creating new fora and discussion' (interview, February 10 2012, New Delhi; personal communication, January 2013).

If INCCA represents a partial continuation of existing developments in climate science in India, then the framing and promotion of the $4 \times 4$ assessment can offer insights into the changing configurations of climate science and policy in the country. Building off MoEF press releases, early media coverage was particularly interested in the idea that INCCA represented something of an 'Indian IPCC' and an indication of India's increasing autonomy 
in scientific matters pertaining to climate change (see e.g. Indian Express, October 14, 2009). As discussed above, this was a framing evident in the minister's foreword to the report.

Politics of time and space

It is also instructive to explore the framing of the scientific study itself, particularly its spatial and temporal coordinates. Climate change as a global risk issue poses distinct challenges to the territorial logic of the modern nation state. Posed as a question of global impacts and international responsibility, climate change knowledges have been most prominently pursued through transnational spaces like the IPCC. However, it is important not to lose sight of the processes through which climate change has been rendered a governable entity at the national scale through the pursuit of knowledges that accord with and extend the historical project of knowing and governing a national territory (cf. Oels, 2005; Whitehead, Jones and Jones, 2007: 203-6). The temporal and spatial coordinates of the INCCA assessment offer insights into how territory and climate change are being brought (and thought) together in a governmental setting.

The INCCA 4x4 Assessment presents projections for the 2030s, an unusual strategy in regional climate prediction, where answers are usually sought for 2050 onwards (Hulme and Dessai, 2008). The desire for projections for the 2030s came from Ramesh himself, and not from the scientists running the regional climate model ${ }^{6}$. It could be surmised that projections for the 2030s were an attempt to reclaim that decade of India's future from the erroneous clutches of the 2035 melting glaciers claim. However, it seems that by locating climate change impacts on a timescale of more human proportions, Ramesh was attempting to inculcate a sense of political urgency amongst his fellow political actors. He offered an additional motivation in a speech he gave in New Delhi in November 2010:

The important thing of this assessment is that it is for the year 2030. It's very important. I want to stress this, because all assessments of climate change are for the year 2060 or 2070 , when none of us will be around. So that's why we are safe when we make all these projections. I told these guys 'you have to make studies and assessments for periods in which you will be alive to be held accountable' [murmuring and laughter in the audience]. (Ramesh, 2010) 
This language of accountability and of not being 'safe' in the temporal distance of one's epistemic claims accords with the co-production of the epistemic and the normative that is clearly evident elsewhere in the episode. Despite the scientists' residing in a government research institution, trust in their predictions is not automatic or given, and the implication is that the scientists would not only be accountable for the accuracy of their predictions, but also in part for the political actions that are taken on the basis of the predictions. Questions of knowledge and of political action thus converge at the temporal horizon of the year 2030 (cf. Beck et al., 2013: 10).

The spatial coverage of the impacts assessment also reveals certain logics of relating predictive knowledge to political action. The initial climate projections used in the INCCA assessment were generated for an area covering the nation as a whole. However, the impacts analysis, for human health and agriculture for example, is conducted for four regions (see Figure 1). This zooming-in was in the first instance an effort to save time, as it is clear that Ramesh wanted a report published quickly. However, the selection of these four regions reveals an interesting territorial logic. The regions don't correspond to conventional climatic or agricultural zones, but rather represent regions of particular natural resource wealth and vulnerability, for example the forests of the North-East and the water resources of the Himalayan region. The tacit metrics of vulnerability by which the regions were selected don't speak of fragile human livelihoods, but rather of national economic and broad-scale ecological security.

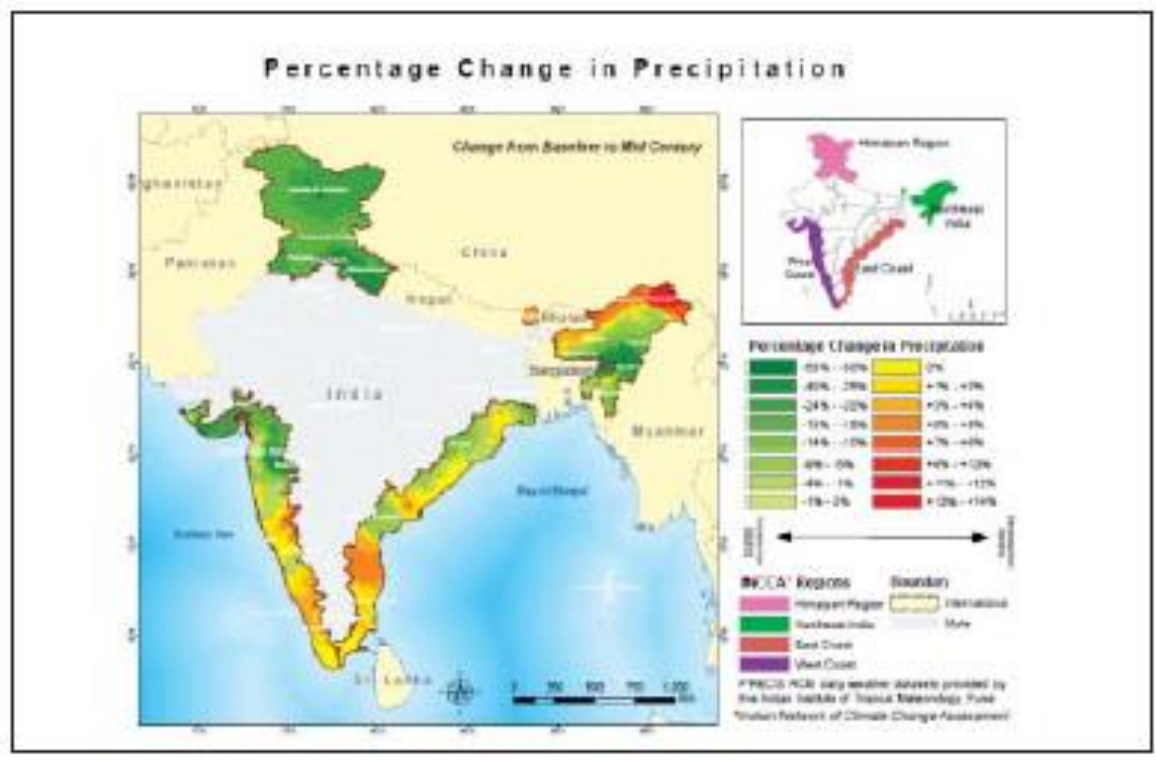


Figure 1. Projected changes in precipitation in the four regions. Source: INCCA, 2010b The projections used in the INCCA assessment were generated by scientists at the Indian Institute of Tropical Meteorology in Pune, which reports to the Ministry of Earth Sciences. The scientists there use a regional climate model called PRECIS that was developed by the UK's Met Office Hadley Centre with the expressed aim of enabling developing countries to produce regional climate scenarios to support adaptation policy making.

PRECIS, which includes a regional climate model and software that enables it to run on any personal computer, is now at work in over 100 countries, and has formed the basis of many national communications under the UNFCCC and other analytic exercises. As a transnational community of actors united by shared epistemic commitments, the PRECIS network illustrates the geographic complexity of climate change knowledge production. Although used here alongside assertions of national scientific autonomy, the model's global spread depends on its association with the prestigious Hadley Centre and on its links with the largely European and North American infrastructures of global climate simulation. ${ }^{7}$ The dynamics of this now global network of regional modellers are explored by Mahony and Hulme (2012).

In the case of Indian knowledge-making, this itinerant climate model has become enmeshed in a new network of epistemic accountability and in articulations of national scientific autonomy. It thus functions as a powerful 'boundary object' (Star and Griesemer, 1989) between the worlds of science and politics, much like the global models from which it is descended (Shackley and Wynne, 1996). Miller (2004) argues that the global gaze offered by climate science and global atmospheric models developed in tandem with the increasingly globalist imagination of a political solution to the knowing and managing of climate change. The exchange of globalist visions of scientific and political order can explain how climate models came to occupy such a prominent position at the science-policy interface, as described by Shackley and Wynne (1996), Demeritt (2001), Oels (2005) and others. In this case, however, the gaze is no longer just global; it is regional or, more precisely, national. A regional model is positioned over the Indian subcontinent and is used to generate national cartographies of environmental change. The question therefore 
becomes: how is this emergent and increasingly popular means of viewing climate change being co-produced with evolving forms of political order?

\section{Governmental knowledges and national space}

The task of addressing this question can be started by considering the broader epistemic landscape within which this predictive knowledge sits. Ramesh, whenever he has spoken of the need for India to act on climate change, has made the claim that India is the country most vulnerable to the effects of climate change. He has described this vulnerability in terms of four facets: the monsoon, the vulnerability of India's forest cover to the demands for mineral resource extraction, the Himalayan glaciers, and coastal vulnerability to rising sea levels.

In the same speech in which he spoke of the accountability of the climate modellers, Ramesh (2010) offered a glimpse of the epistemic underpinnings of this claim. The monsoon vulnerability he describes by discussing a correlation between GDP growth rates and monsoon variability. ${ }^{8}$ On forests, he depicts a spatial correlation between forest areas and areas of mineral wealth. On glaciers, he notes the dependence of many millions of people on the water that springs from the Himalayan range, but, like Raina (2009), he does not offer a particular sense of the glaciers' future under climate change. One Indian NGO grouping deems this ambiguity as tantamount to 'climate denialism' (CCI Coalition, 2008). On coastal vulnerabilities, Ramesh states that 'if there is one robust scientific conclusion that has been reached after 20 years of research on climate change, the one thing on which there is no controversy is the rise in mean sea levels' (cf. O’Reilly, Oreskes and Oppenheimer, 2012).

Together, these claims constitute an archetypal collection of government knowledges variously ambiguous and certain international science, the oscillations of the national economy as measured by a single metric that seeks to capture all the productive activity taking place within a pre-defined national space, and the spatial coincidence of two types of resource - mineral and arboricultural, as observable on a map of the country's resource richness. The latter two examples represent the kind of the governmental gaze described by James Scott in Seeing Like a State (1998), the homogenizing and ordering eye of political power (also Sivaramakrishnan, 1999). The construction, especially by the state, of forest 
areas in particular as collections of resources for national exploitation rather than spaces of human habitation and ecological interdependence is a long-standing object of critique in India (Guha, 2006: 90-124).

This collection of ways of knowing a national space suggests that when climate change and its implications come to be known at the national level, the process is much more complex than just downscaling the results of global climate projections. Rather, 'downscaling' climate change means that the idea comes into contact with a number of political and cultural norms and ways of knowing that, this episode suggests, will be unique to particular national and even sub-national contexts. Climate change predictions are integrated into longer stories of national progress, of collective experiences and risks, and different logics of relating economy, government, environment, and national space (cf. Jasanoff and Martello, 2004).

These logics have informed and reinforced India's approach to international climate negotiations, with the norms of per capita responsibility and the right to development informing India's resistance to binding emissions targets since the inception of the UN negotiations (Dasgupta, 2011). However, in the period in which this study is situated, a noticeable shift in India's stance took place. This began in 2007 with Prime Minister Manmohan Singh announcing that India's per capita emissions would never exceed those of industrialized countries, essentially introducing for the first time the idea of a national emissions cap. By the time of COP16 in 2010, Ramesh had introduced the notion of 'equitable access to sustainable development', which can be seen as an attempt to mediate between the long-institutionalized concerns for equity and material development and an apparent desire to be seen to play a more constructive role in international negotiations (Atteridge et al., 2012; Dubash, 2009; Stevenson, 2011).

Indian negotiators, along with their US counterparts, were at the forefront of moves to inculcate a 'pledge-and-review' system of emissions cuts, whereby nation-states would voluntarily pledge mitigation actions that would then be monitored by international bodies (see Hare et al., 2010). These moves led to fierce debates in parliament between the minister and those who saw Ramesh as ceding sovereignty to outside actors, or as one Member of Parliament put it, 'gifting away our carbon space'. However, Ramesh countered 
such concerns by re-affirming his vision of India's unique vulnerability, and by arguing that incidents when Indian science has countered the received wisdom demonstrate that the country does not need to be defensive when it comes to the international monitoring of domestic mitigation efforts (Prabhu, 2011).

For some commentators, the policy shift between 2007 and 2010 resulted from a fear of isolation on the global stage. At the same time, many domestic actors and campaigners, such as those at CSE, criticized Ramesh for what they perceived as an attempt to align India's position with that of the US, and for uncritically embracing neoliberal approaches to mitigation such as market mechanisms and transnational carbon abatement (e.g. D'Monte, 2009). Ramesh's manoeuvrings were seen as running counter to the demands of poverty reduction, livelihood protection, and economic sovereignty, while extending the government's embracing of a neoliberal, globalist discourse and economic paradigm (Atteridge et al., 2012).

Such rifts occurred even within the government's climate negotiation team, with several veteran members only agreeing to go with Ramesh to the 2009 Copenhagen negotiations after eleventh-hour efforts at reconciliation. However, Ramesh also at times stressed a need to de-link domestic policy actions from the international proceedings, stating for example in 2010 that:

Unfortunately, our approach to climate change has been unduly influenced by international negotiations. We need to de-link what we do from international negotiations. We need to ask ourselves the question 'what is in our interest?' and mount the appropriate response. (Ramesh, 2010)

Statements such as these illustrate arguments put forward by Kythreotis (2012) that the reassertion of nation state territoriality in the recent evolution of the climate change debate challenges the commonly idealized vision of a post-political consensual environment of international collectivism (see Swyngedouw, 2010). The concept of territoriality, conceived by Kythreotis as the relational effect of uneven economic power and the articulation of interests and differences within and between state borders, offers a powerful way of understanding the partial fragmentation of the global climate governance regime and the 
groundswell of support for more 'bottom-up' approaches to climate politics (Biermann and Pattberg, 2009; Kythreotis, 2012).

The 'pledge-and-review' approach can be read as an attempt to articulate territoriality within a policy architecture that has historically been geared towards multilateral agreement (cf. Hare et al., 2010). State-based processes of emissions accounting such as the INCCA inventory (INCCA, 2010a) produce 'a peculiar situation whereby a territorial substance.... which contributes to a change in the operation of natural systems at a postterritoriality scale, is conceived of, classified, and managed through its association with the persistent territorialities of nation-states' (Whitehead et al., 2007: 205; see also Lövbrand and Stripple, 2011). Like INCCA's (2010b) predictions, this act of measurement and classification reconstitutes territory as a form of political order in the face of the deterritorializing potential of the carbon dioxide molecule (cf. Agarwal and Narain, 1991).

Ramesh's characterization of Indian domestic policy being 'unduly influenced by international negotiations' restates and responds to criticisms of the government's overriding focus on the UNFCCC process and its eschewing of other ways of knowing and acting upon climate change. INCCA has informed the arguments for delinking domestic and international policy action. Predictive knowledge of the national territory is seen as offering the Indian government the means to pursue mitigation and adaptation policies independently of the international scientific and political processes. With the addition of renewed knowledge of national emissions, national territory becomes a newly governable space in which particular forms of political action can be exercised by a government sensitive to criticism that it has ceded nation-state sovereignty over the Indian economy and environment. However, the resistances to Ramesh's efforts to alter the terms of India's engagement with international climate mitigation negotiations, particularly efforts to enmesh the state in a new, highly disputed form of neoliberal globalism, are reminders that the redefinition of what, as Ramesh put it, is 'in our interest', is a contested terrain. Territoriality and territory are not pre-given in such debates. Rather, like the nation-state itself, they are constituted through networks 'held together by circulating technologies of representation and communication' (Jasanoff, 2004a: 26; see also Elden, 2007). The participation of climate models in these processes marks an important extension and re- 
casting of longer traditions of national knowledge-making (Edney, 1997; Scott, 1998; Sivaramakrishnan, 1999).

\section{Conclusions}

Territory, as a form of social order, is both premised on and generative of certain kinds of governmental knowledge-making, particularly the measurement and calculation of space and spatial relationships. In the case offered here we can see a re-emergence or perhaps recoding of territory as an epistemic object. That re-coding is evident, for example, in new temporal coordinates. Specifically, there is an emerging concern with the future of territory, in efforts to induce a new anticipative approach to problems of resource management and human development, and in order to persuade and convince other political actors of the need to transform the state's engagement with both domestic and international climate politics. Territory is mediated through a didactic futurology, by which it comes to figure as an object of combined epistemic and normative contestation (cf. Beck et al., 2013: 9-12; Hulme, 2010b).

As I've sought to demonstrate, new territorial knowledges have come about amid a set of very particular responses to the nature of international science and the changing nature of international climate politics. Although many countries across the world are now pursuing what we might think of as territorial knowledge of the future (see e.g. Jenkins et al, 2009 for the UK; MoST, 2011 for China), in India the form of this emergent knowledge has been shaped by the context of a complex and at times antagonistic relationship with the so-called 'Western' science of the IPCC. The controversy over the melting glaciers claim reanimated themes of epistemic and political sovereignty which have long informed climate politics in India. A persistent pattern of epistemic and normative intermixing situates predictive knowledge claims within a framework of scientific accountability and national autonomy, in a powerful illustration of how the science and politics of climate change are mutually constituted. This is the quintessential co-productionist understanding of climate change. But I have suggested that in this case, the co-production of the epistemic and the normative has a particular valence, to the point where a co-productionist understanding of science and politics becomes a strategic instrument in the ongoing construction of social order. 
It is in this sense that we might begin to think about the agonistic co-existence of different co-productions, particularly in the different strategies of reproducing the nation-state in the putative global space of international climate science and politics. Recalling the incident with which I opened the article, the Indian chair of the IPCC rebuffed the Indian government's challenge to IPCC claims by dismissing them as 'arrogant' and 'voodoo science'. In defending the space of global science against governmental attack, Rajendra Pachauri sought to discredit the government's scientific claims by painting them as politically-driven and scientifically disreputable. A number of Indian environmental NGOs have similarly argued for the subordination of the nation-state to the authority of global science, although bodies like CSE have long argued for the strident defense of national sovereignty in the international politics of climate change. In his own response to the glacier error, Jairam Ramesh sought to re-inscribe the national in the global space of climate science and politics by articulating (and practicing) an epistemic sovereignty alongside moves to re-order the relationship between national and international climate policy. Ramesh's political 'internationalism' (Dubash, 2013) was thus distinct from the kind of epistemic globalism (Miller, 2009) mobilised by Pachauri. Ramesh's efforts to re-inscribe the national in international climate politics (through embracing strategic alliances and voluntary pledges) did not, however, sit comfortably with the way CSE articulated the relationship between knowledge and action, and national and global . These different coproductions of knowledge and social order co-exist in dynamic and agonistic tension, with science playing different roles in each. Disentangling such articulations of space, knowledge and power may be aided by renewed empirical and conceptual exchange between STS and critical human geography.

My observations about the re-emergence of territory as a political object in climate debates concur with a number of arguments that have been advanced regarding the fragmentation of the global climate governance architecture and the seeming re-assertion of nation state territoriality and sovereignty in questions about ethics, responsibility and development rights (Biermann and Pattberg, 2009; Kythreotis, 2012; Prins et al., 2010). However, the way in which the climate becomes a knowable object in national contexts is contingent both on transnational knowledge networks, such as the PRECIS system, that challenge assertions of scientific autonomy, and on local modes of authorising and acting upon knowledge, or 'civic 
epistemologies' (Jasanoff, 2005a). In turn, the ways in which the climate re-emerges as a local object, described in terms of national space, may begin to shape how states conceive their very sovereignty and responsibility to their own citizens and to others (Jasanoff and Martello, 2004; Beck, 2009).

It is in this sense that it is vital to further explore the co-production of territory in the complex relationship between climate science and politics. Through the study of controversy and emergence, insights can be gained into the processes by which the epistemic and the normative mutually shape and condition each other in the ongoing construction of political order. The idiom of co-production therefore has the potential to contribute to the project of historicizing the role of scientific rationalities in the production of particular forms of spatial organization, such as territory, and to offer new insights into the evolving spatiality of the nation-state in an era of apparent epistemic and political globalization.

\section{References}

Agarwal A (2001) Science is a political orphan. Down to Earth, 28 February.

Agarwal A and Narain S (1991) Global Warming in an Unequal World: A Case of Environmental Colonialism. New Delhi: Centre for Science and Environment.

Agarwal A, Sharma K and Chopra R (1982) State of India's Environment: A Citizen's Report. New Delhi: Centre for Science and Environment.

Agarwal A, Narain S and Sharma A (1999) Green Politics. New Delhi: Centre for Science and Environment.

Agnew J (1994) The territorial trap: The geographical assumptions of international relations theory. Review of International Political Economy 1(1): 53-80.

Anderson B (1983) Imagined communities. London: Verso.

Anderson K (2005) Predicting the Weather: Victorians and the Science of Meteorology. Chicago, IL: University of Chicago Press.

Atteridge A, Shrivastava M, Pahuja N, and Upadhyay H (2012) Climate policy in India: What shapes international, national and state policy? Ambio 41(1): 68-77.

Bagla P (2009) Climate change: No sign yet of Himalayan meltdown, Indian report finds. Science 326(5955): 924-5. 
Banerjee B and Collins G (2010) Anatomy of IPCC's mistake on Himalayan glaciers and year 2035. The Yale Forum on Climate Change and the Media. Available at: http://www.yaleclimatemediaforum.org/2010/02/anatomy-of-ipccs-himalayan-glacieryear-2035-mess/ accessed 2 November 2012.

Baudrillard J (1983) Simulations. Los Angeles, CA: Semiotext(e).

Beck S (2012) Between tribalism and trust: The IPCC under the 'public microscope'. Nature and Culture 7(2): 151-173.

Beck U (2009) World at Risk. Cambridge: Polity.

Beck U, Blok A, Tyfield D and Zhang JY (2013) Cosmopolitan communities of climate risk: Conceptual and empirical suggestions for a new research agenda. Global Networks 13(1): 1-21.

Biermann F (2001) Big science, small impacts -in the South? The influence of global environmental assessments on expert communities in India. Global Environmental Change 11(4): 297-309.

Biermann F and Pattberg P (2009) The fragmentation of global governance architectures: A framework for analysis. Global Environmental Politics 9(4): 14-40.

Braun B (2000) Producing vertical territory: Geology and governmentality in late Victorian Canada. Cultural Geographies 7(1): 7-46.

CCI Coalition (2008) India's National Action Plan on Climate Change: An interim assessment by the 'Climate Challenge India' Coalition. Bangalore.

Charmaz K (2006) Constructing Grounded Theory: A Practical Guide through Qualitative Analysis. London: Sage.

Crampton JW (2010) Cartographic calculations of territory. Progress in Human Geography 35(1): 92-103.

Dasgupta C (2011) Present at the creation: The making of the UN Framework Convention on Climate Change. In: Dubash NK (ed) Handbook of Climate Change and India. London: Earthscan, 89-97.

Demeritt D (2001) The construction of global warming and the politics of science. Annals of the Association of American Geographers 91(2): 307-337.

D'Monte D (2009) India's climate volte face: Tragedy or farce? Infochange India. Available at: http://infochangeindia.org/environment/eco-logic/indias-climate-volte-face-tragedyor-farce.html accessed 11 July 2013.

Dubash NK (2009) Toward a progressive Indian and global climate politics. Centre for Policy Research Working Paper 2009/1. New Delhi. 
Dubash NK (ed) (2011). Handbook of Climate Change and India: Development, Politics and Governance. London: Routledge.

Dubash NK (2013) The politics of climate change in India: Narratives of equity and cobenefits. Wiley Interdisciplinary Reviews: Climate Change 4: 191-201.

Edney MH (1997) Mapping an Empire: The Geographical Construction of British India, 17651843. Chicago, IL: University of Chicago Press.

Elden S (2010) Land, terrain, territory. Progress in Human Geography 34(6): 799-817.

Elden S (2007) Governmentality, calculation, territory. Environment and Planning D: Society and Space 25(3): 562-580.

Ezrahi Y (1990) The Descent of Icarus. Cambridge: Harvard University Press.

Gadgil M and Guha R (1993) This Fissured Land. Berkeley, CA: University of California Press.

Gieryn TF (1983) Boundary-work and the demarcation of science from non-science: Strains and interests in professional ideologies of scientists. American Sociological Review 48(6): 781-795.

Goswami M (2004) Producing India: From Colonial Economy to National Space. Chicago, IL: University of Chicago Press.

Guha R (2006) How Much Should a Person Consume? Environmentalism in India and the United States, Berkeley, CA: University of California Press.

Haberman DL (2006) River of Love in an Age of Pollution: The Yamuna River of Northern India. Berkeley, CA: University of California Press.

Hare $W$ et al. (2010) The architecture of the global climate regime: A top-down perspective. Climate Policy 10(6): 600-614.

Hawkins E and Sutton R (2009) The potential to narrow uncertainty in regional climate predictions. Bulletin of the American Meteorological Society 90(8): 1095-1107.

Hindustan Times (2009) Government quells panic over Himalayan glacier melt. 10 November. Available at: http://www.hindustantimes.com/News-Feed/India/Govtquells-panic-over-Himalayan-glacial-melt/Article1-474713.aspx accessed 24 February. 2012

Hindustan Times (2010) Won't let Pachauri down in IPCC: Govt. 16 March. Available at: http://www.hindustantimes.com/India-news/NewDelhi/Won-t-let-Pachauri-down-inIPCC-Govt/Article1-519479.aspx accessed 24 February.

Ho-Lem C, Zerriffi H and Kandlikar M (2011) Who participates in the Intergovernmental Panel on Climate Change and why: A quantitative assessment of the national 
representation of authors in the Intergovernmental Panel on Climate Change. Global Environmental Change 21(4): 1308-1317.

Hulme M (2009) Why We Disagree About Climate Change: Understanding Controversy, Inaction and Opportunity. Cambridge: Cambridge University Press.

Hulme M (2010a) Problems with making and governing global kinds of knowledge. Global Environmental Change 20(4): 558-564.

Hulme M (2010b) Cosmopolitan climates: Hybridity, foresight and meaning. Theory, Culture and Society 27(2-3): 267-276.

Hulme M and Dessai S (2008) Negotiating future climates for public policy: A critical assessment of the development of climate scenarios for the UK. Environmental Science and Policy 11(1): 54-70.

Humphreys P (2009) The philosophical novelty of computer simulation methods. Synthese 169(3): 615-626.

INCCA (2010a) India: Greenhouse Gas Emissions 2007. New Delhi: Ministry of Environment and Forests, Government of India.

INCCA (2010b). Climate change and India: A 4x4 Assessment, New Delhi: Ministry of Environment and Forests, Government of India.

Indian Express (2009) Expert says $\mathrm{CO}_{2}$ needed for growth, cutting soot helps. 14 October. Available at: http://www.indianexpress.com/news/climate-science-mired-in-politicsjairam/801199 accessed 24 February 2012

Indian Express (2011) Climate science mired in politics: Jairam. 9 June. Available at: http://www.indianexpress.com/news/climate-science-mired-in-politics-jairam/801199 accessed 24 February 2012.

IPCC (2007) Asia. In: Parry ML et al. (eds) Climate Change 2007: Impacts, Adaptation and Vulnerability. Contribution of Working Group II to the Fourth Assessment Report of the Intergovernmental Panel on Climate Change. Cambridge: Cambridge University Press, 469-506.

Jasanoff S (1988) The Bhopal disaster and the right to know. Social Science and Medicine 27(10): 1113-1123.

Jasanoff S (2004a) Ordering knowledge, ordering society. In: Jasanoff S (ed) States of Knowledge: The Co-Production of Science and Social Order. London: Routledge, 13-45.

Jasanoff S (2004b) The idiom of co-production. In: Jasanoff S (ed), States of Knowledge: The Co-Production of Science and Social Order. London: Routledge, 1-12. 
Jasanoff S (2004c) Afterword. In: Jasanoff S (ed), States of Knowledge: The Co-Production of Science and Social Order. London: Routledge, 274-282.

Jasanoff S (2004d) Heaven and Earth: The politics of environmental images. In: Jasanoff S and Martello ML (eds) Earthly Politics: Local and Global in Environmental Governance. Cambridge, MA: MIT Press, 31-52.

Jasanoff S (2005a) Designs on Nature: Science and Democracy in Europe and the United States. Princeton, NJ: Princeton University Press.

Jasanoff S (2005b) Restoring reason: Causal narratives and political culture. In: Hutter B and Power M (eds) Organizational Encounters with Risk. Cambridge: Cambridge University Press, 209-232.

Jasanoff S (2007) Bhopal's trials of knowledge and ignorance. Isis 98: 344-350.

Jasanoff S (2010) A new climate for society. Theory, Culture and Society 27(2-3): 233-253.

Jasanoff S (ed) (2011) Reframing Rights: Bioconstitutionalism in the Genetic Age. Cambridge, MA: MIT Press.

Jasanoff S and Martello ML (eds) (2004) Earthly Politics: Local and Global in Environmental Governance. Cambridge, MA: MIT Press.

Jenkins G et al. (2009) UK Climate Projections: Briefing Report. Oxford: Climate Impacts Programme.

Kandlikar M and Sagar A (1999) Climate change research and analysis in India: An integrated assessment of a South-North divide. Global Environmental Change 9(2): 119-138.

Kythreotis AP (2012) Progress in global climate change politics? Reasserting national state territoriality in a 'post-political' world. Progress in Human Geography 36(4): 457-474.

Lahsen M (2007) Trust through participation? Problems of knowledge in climate decision making. In: Pettenger ME (ed) The Social Construction of Climate Change. Farnham: Ashgate, 173-196.

Lele S (2011) Climate change and the Indian environmental movement. In Dubash NK (ed) Handbook of Climate Change and India. London: Earthscan, 208-217.

Livingstone DN (2003) Putting Science in its Place: Geographies of Scientific Knowledge. Chicago, IL: University of Chicago Press.

Lövbrand E (2011) Co-producing European climate science and policy: A cautionary note on the making of useful knowledge. Science and Public Policy 38(3): 225-236.

Lövbrand E and Stripple J (2011) Making climate change governable: Accounting for carbon as sinks, credits and personal budgets. Critical Policy Studies 5(2): 187-200. 
Mahony M and Hulme M (2012) Model migrations: Mobility and boundary crossings in regional climate prediction. Transactions of the Institute of British Geographers 37(2): 197-211.

Masood E (1995) Developing countries dispute use of figures on climate change impacts. Nature 376(6539): 374-374.

Miller CA (2004) Climate science and the making of a global political order. In: Jasanoff S (ed) States of Knowledge: The Co-Production of Science and Social Order. London: Routledge, 46-66.

Miller CA (2009) Epistemic constitutionalism in international governance: the case of climate change. In: eazle M, Griffiths M and Conley T (eds) Foreign Policy Challenges in the 21st Century. Cheltenham: Edward Elgar, 141-163.

Mitchell T (2002) Rule of Experts: Egypt, Techno-Politics, Modernity. Berkeley, CA: University of California Press.

MoEF (2009) Climate Change and India: Towards Preparation of a Comprehensive Climate Change Assessment. New Delhi: Ministry of Environment and Forests, Government of India.

Moors EJ et al. (2011) Adaptation to changing water resources in the Ganges basin, northern India. Environmental Science \& Policy 14(7): 758-769.

MoST (2011) Second National Climate Change Assessment Report. Beijing: Ministry of Science and Technology of the People's Republic of China.

Norton DW (2010). Constructing 'Climategate' and Tracking Chatter in an Age of Web n.O, Washington, DC: American University Center for Social Media.

Oels A (2005) Rendering climate change governable: From biopower to advanced liberal government? Journal of Environmental Policy and Planning 7(3): 185-207.

O’Reilly J (2011) Tectonic history and Gondwanan geopolitics in the Larsemann Hills, Antarctica. Political and Legal Anthropology Review 34(2): 214-232.

O'Reilly J, Oreskes N and Oppenheimer M (2012) The rapid disintegration of projections: The West Antarctic ice sheet and the Intergovernmental Panel on Climate Change. Social Studies of Science, 42(5): 709-731.

Parashar DC et al. (1996) Methane budget from paddy fields in India. Chemosphere, 33(4): 737-757.

Pickles J (2004) A History of Spaces: Cartographic Reason, Mapping, and the Geo-Coded World, London: Routledge.

Porter T (1995) Trust in Numbers. Princeton, NJ: Princeton University Press. 
Prabhu S (2011) Climate change and parliament. In: Dubash NK (ed) Handbook of Climate Change and India. London: Routledge, 230-245.

Prins G et al. (2010) The Hartwell Paper: A new direction for climate policy after the crash of 2009. Oxford: Institute for Science, Innovation and Society.

Raghunandan D (2011) India's official position: a critical view based on science. In: Dubash NK (ed) Handbook of Climate Change and India. London: Earthscan, 170-180.

Raina VK (2009) Himalayan Glaciers: A State-of-Art Review of Glacial Studies, Glacial Retreat and Climate Change. New Delhi: Ministry of Environment and Forests, Government of India.

Ramesh J (2010) Inaugural address. National Policy Dialogue on Climate Change Actions, 12 November, New Delhi. Available at:

http://www.climatechangeaction.in/workshop/delhi/ accessed 17 February 2012.

Scott JC (1998). Seeing like a State: How Certain Schemes to Improve the Human Condition have Failed, New Haven, CT: Yale University Press.

Shackley S and Wynne B (1996) Representing uncertainty in global climate change science and policy: Boundary-ordering devices and authority. Science, Technology and Human Values 21(3): 275-302.

Shapin S (1998) Placing the view from nowhere: Historical and sociological problems in the location of science. Transactions of the Institute of British Geographers, 23(1): 5-12.

Shapin S and Schaffer S (1985) Leviathan and the Air-Pump: Hobbes, Boyle, and the Experimental Life. Princeton, NJ: Princeton University Press.

Sharma A and Gupta A (2006) Introduction: Rethinking theories of the state in an age of globalization. In: Sharma A and Gupta A (eds) The Anthropology of the State: A Reader. Oxford: Blackwell, pp. 1-41.

Sivaramakrishnan K (1999) Modern Forests: Statemaking and Environmental Change in Colonial Eastern India. Oxford: Oxford University Press.

Star SL and Griesemer JR (1989) Institutional ecology, 'translations' and boundary objects: Amateurs and professionals in Berkeley's Museum of Vertebrate Zoology, 1907-39. Social Studies of Science 19(3): 387-420.

Stevenson H (2011) India and international norms of climate governance: a constructivist analysis of normative congruence building. Review of International Studies 37(3): 9971019.

Sundberg M (2006) Translating climate research: The role of IPCC. In: Towards robust European air pollution policies: Constraints and prospects for a wider dialogue between 
scientists, experts, decision-makers and citizens. A workshop report. IVL Rapport B1671, 51-54

Swyngedouw E (2010) Apocalypse forever? Post-political populism and the spectre of climate change. Theory, Culture \& Society 27(2-3): 213-232.

Varma R (2001) People's Science Movements and science wars? Economic and Political Weekly 36(52): 4796-4802.

Visvanathan S (2005) Knowledge, justice and democracy. In: Leach M, Scoones I and Wynne B (eds) Science and Citizens. London: Zed Books, 83-94.

Weber M (1946) Essays from Max Weber. London: Routledge \& Kegan Paul.

Whatmore SJ (2009) Mapping knowledge controversies: Science, democracy and the redistribution of expertise. Progress in Human Geography 33(5): 587-598.

Whitehead M, Jones R and Jones M (2007) The Nature of the State: Excavating the Political Ecologies of the Modern State. Oxford: Oxford University Press.

Wilson Rowe E (2012) International science, domestic politics: Russian reception of international climate-change assessments. Environment and Planning D 30(4): 711-726.

Winichakul T (1994) Siam Mapped: A History of the Geo-Body of the Nation. Honolulu: University of Hawaii Press.

Wood D (1992) The Power of Maps. New York: Guilford Press.

\section{Acknowledgments}

This paper was prepared during a Visiting Fellowship on the Science, Technology and Society Program at the Harvard Kennedy School of Government. I am especially grateful to Sheila Jasanoff for her invitation, guidance and inspiration, and to Shana Rabinowich for all her assistance. Thanks to all the Fellows for their insights and collegiality, and also to Mike Hulme and Helen Pallett for their important comments. I also wish to thank Sergo Sismondo, Mark Vardy and the four reviewers for helping me sharpen my argument. I am greatly indebted to all my interview respondents and to the Centre for Science and Environment, particularly Priyanka Dutta, Jagdeep Gupta, Mr. Bains, Anju Sharma and everyone on the CSE climate change team for their hospitality and assistance during my fieldwork. The support of an Economic and Social Research Council studentship (number ES/H01110/1) is gratefully acknowledged.

\section{Biographical note}

Martin Mahony is a postgraduate researcher in the Science, Society and Sustainability (3S) Research Group at the University of East Anglia, UK. He is currently completing his PhD thesis, entitled Epistemic Geographies of Climate Change: The IPCC and the Spaces, 
Boundaries and Politics of Knowing. Working at the intersection of STS and the nascent field of geography of science, his work investigates the cultural geographies of climate change knowledges and the practices and politics of scientific assessments and simulation modelling. He has published articles on regional climate simulation, scientific visualization, and the negotiation of scientific knowledge claims in international climate negotiations.

\section{[Endnotes]}

\footnotetext{
${ }^{1}$ On the links between rivers, religious thought and environmental science and politics in India, see Haberman (2006) and O'Reilly (2011).

${ }^{2}$ See also The Guardian's interview with Pachauri: 'India "arrogant" to deny global warming link to melting glaciers', 9 November 2009.

${ }^{3}$ Pachauri's denigration of the Indian government's report in this register led Silke Beck (2012) to criticize the IPCC leadership's tendency to position themselves as gatekeepers in the climate debate, dismissing uncomfortable questions as politically-motivated attacks, while often failing to engage with the substantive issues being raised. Beck argues that this tactic, of dismissing the messenger before engaging with the message, is ironically reminiscent of the agonistic tactics which climate sceptics or deniers are accused of using.

${ }^{4}$ The controversy quickly garnered these labels in media coverage and on blogs written by commentators sceptical of the reality or severity of anthropogenic climate change. As Norton (2010) has shown, the 'Climategate' nomenclature emerged through complex iterative processes enabled by new social media, rather than being a concerted, strategic discursive act.

${ }^{5}$ The IPCC has a trust fund to support the participation of scientists from developing countries, but other financial and bureaucratic constraints - like visas and working time - still preclude fuller participation, alongside broader issues of language barriers and the diverse nature of climate expertise. See Biermann (2001) and Ho-Lem et al. (2011).

${ }^{6}$ How the years 2050 and 2100 came be stabilised as future-visioning horizons at the science-policy interface is an interesting empirical question. In regional climate modelling, near-term projections (e.g. for the 2030s) can be problematic due to the prevalence of uncertainties relating to the 'internal variability' of regional climates. See Hawkins and Sutton (2009).

${ }^{7}$ Mahony and Hulme (2012) argue that the wide application of PRECIS has been achieved by the packaging of the model into a 'black box', meaning that users are unable to see or change the computer code which underlies the model, and thus they are unable to consider the sensitivity of their regional scenarios to the unique characteristics of the model. This is a problem which some philosophers of science have called 'epistemic opacity' - raising the question of whether one needs to know what's going on inside a model in order to make sense of what comes out of it (e.g. Humphreys, 2009).

${ }^{8}$ On the links between the monsoon, an emergent meteorology and colonial political economy in India, see Anderson (2005).
} 